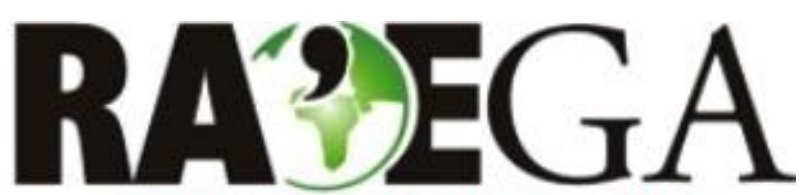

O ESPAÇO GEOGRÁFICO EM ANÁLISE

\title{
NITROGEN USE EFFICIENCY: A LOCAL AND REGIONAL APPROACH FOR BRAZILIAN AGRICULTURE
}

\section{EFICIÊNCIA DO USO DO NITROGÊNIO: ABORDAGEM LOCAL E REGIONAL PARA A AGRICULTURA BRASILEIRA} Karina Lima Tôsto ${ }^{1}$, Felipe Siqueira Pacheco ${ }^{2}$, Luciene Gomes $^{3}$, Marcela Miranda ${ }^{4}$, Simoni Maria Loverde
Oliveira ${ }^{5}$, Dhonatan Diego Pessi ${ }^{6}$, Christopher Cox $^{7}$ Jean Pierre Henry Balbaud Ometto

\begin{abstract}
The exponential growth of human activities has been significantly altering the global Nitrogen $(\mathrm{N})$ cycling. Due to the scale of these changes, integrated approaches are required to optimize nutrient cycles to meet food and energy demands, while minimizing threats to climate, ecosystem services, and human health. Brazil is now in a leading position on the world stage as one of the great producers and exporters of agricultural products, and must reconcile the expansion of this sector with environmental preservation and promotion of social equity. The Nitrogen Use Efficiency (NUE) is a tool to evaluate the progress of its management, and can be estimated by the ratio between the outflows and $\mathrm{N}$ inputs in the agro systems. In this study, NUE was calculated on different scales: regional, covering the entire Brazilian territory, and local, comprising the Vermelho River watershed, an important agricultural area of the Upper Pantanal. The spatialized results indicate great heterogeneity in the NUE, with most of the Brazilian states presenting values outside the desirable range. Low efficiency in nutrient use is identified in several states of Northeast and Southeastern Brazil. On the other hand, regions of great agricultural importance in the Cerrado have high values, suggesting that the $\mathrm{N}$ exports by the products outweigh the replacement of this element, which can lead to N mining and degradation of productive land. On a local scale, NUE is very close to the desirable ceiling, with subtle reduction between 2000 and 2015.
\end{abstract}

Keywords: agricultural production, fertilizer, biological fixation, Cerrado, Pantanal.

\section{RESUMO}

$\mathrm{O}$ crescimento exponencial das atividades humanas vem alterando de maneira significativa a ciclagem global do Nitrogênio (N). Devido a escala dessas mudanças, são necessárias abordagens integradas que otimizem os ciclos de nutrientes para suprir as demandas por alimentos e energia, ao mesmo tempo em que minimizem as ameaças ao clima, serviços ecossistêmicos e saúde humana. O Brasil se encontra hoje em uma posição de destaque no cenário mundial como um dos grandes produtores e exportadores de produtos agrícolas, e precisa conciliar a expansão desse setor com a preservação ambiental e promoção da equidade social. A Eficiência do Uso do Nitrogênio (NUE) consiste em uma ferramenta para avaliação do progresso do seu manejo, e pode ser estimada pela razão entre as saídas e entradas de $\mathrm{N}$ nos agrossistemas. Nesse trabalho, a NUE foi calculada em diferentes escalas: regional, abrangendo todo o território brasileiro, e local, compreendendo a bacia do rio Vermelho, importante área agrícola do Alto Pantanal. Os resultados espacializados indicam grande heterogeneidade na NUE, com grande parte dos estados brasileiros apresentando valores fora dos limites desejáveis. Baixa eficiência no uso do nutriente é identificada em diversos estados do nordeste e sudeste brasileiro. Por outro lado, regiões de grande importância agrícola no Cerrado apresentam altos valores, sugerindo que as exportações de $\mathrm{N}$ pelos produtos superam a reposição desse elemento, podendo levar a mineração do $\mathrm{N}$ e degradação da terra produtiva. Em escala local, a NUE está muito próxima ao limite máximo desejável, com sutil redução entre 2000 e 2015.

Palavras chave: produção agrícola, fertilizante, fixação biológica, Cerrado, Pantanal.

\footnotetext{
1 Instituto Nacional de Pesquisas Espaciais, São José dos Campos/SP, e-mail: karina.tosto@inpe.br

2 Instituto Nacional de Pesquisas Espaciais, São José dos Campos/SP, e-mail: felipe.pacheco@inpe.br

3 University of Leeds, Leeds/United Kingdom, e-mail: lucienegomes178@gmail.com

4 Instituto Nacional de Pesquisas Espaciais, São José dos Campos/SP, e-mail: marcelaacnmiranda@gmail.com

${ }_{5}^{5}$ Universidade Federal de Mato Grosso, Rondonópolis/MT, e-mail: si.loverde@hotmail.com

${ }^{6}$ Universidade Federal de Mato Grosso, Rondonópolis/MT, e-mail: dhonatan.pessi@gmail.com

7 United Nations Environment Programme, Nairobi/ Kenya, e-mail: christopher.cox@unep.org

8 Instituto Nacional de Pesquisas Espaciais, São José dos Campos/SP, e-mail: jean.ometto@inpe.br
} 


\section{INTRODUCTION}

Nitrogen $(\mathrm{N})$ is an essential nutrient for all living beings and plays a critical role in primary production (VITOUSEK et al., 2009; STEIN; KLOTZ, 2016). The exponential growth of human activities in the last century has dramatically altered the availability and global cycling of this element, bringing both direct benefits (improvements in the agricultural system productivity), but also leading to negative impacts on the environment and human health (SUTTON et al., 2013; GALLOWAY et al., 2014; STEFFEN et al., 2015).

Agricultural systems are currently the main responsible for changes in the $\mathrm{N}$ cycle, mostly due to the use of synthetic fertilizers in crops and expansion of cultivated areas with nitrogen-fixing species (FOWLER et al., 2013). N is a key element to ensure the production of food, fiber and biofuel. Therefore, it will continue to be crucial in promoting hunger eradication as well as in supplying the growing global population and increasing per capita consumption (DAVIDSON et al., 2016). The agricultural productivity of many places is still limited by $\mathrm{N}$, as in parts of Africa and Latin America, contributing to land degradation and abandonment (LAL, 2014; REIS et al., 2016). Also, excess and misuse of $\mathrm{N}$ are observed in some agro-systems, leading to water bodies and atmosphere losses (ERISMAN et al., 2015; KANTER; SEARCHINGER, 2018).

The main negative impacts include alterations in greenhouse gases balance, ozone creation in the troposphere and its depletion in the stratosphere, particulate matter production, ocean acidification and reduction on continental waters quality and availability due to eutrophication process (FOWLER et al., 2013). In order to promote a better management and cycling optimization, the consequences of nutrients excess in some regions and deficiencies in others have been debated in the national and international scientific community, considering food security while reducing threats to climate, ecosystem services, health and human well-being (BILLEN et al., 2011). Given the complexity of the $\mathrm{N}$ cycle, promoting its proper management is not an easy task (OENEMA et al., 2015). Thus, the term "Nutrient Challenge" emerged within the framework of international discussions to represent one of the greatest challenges imposed by contemporary society, which is to ensure world population nutrition, estimated to reach more than 9 billion people by 2050, considering the potential impacts of the growing need for food production (UNITED NATIONS, 2017).

Improving $\mathrm{N}$ management offers a unique opportunity to maximize the chances of achieving many of the Sustainable Development Goals (SDGs), since $\mathrm{N}$ inputs are crucial to the global food system and also a major source of pollution (DOBERMANN, 2016; KANTER; ZHANG; HOWARD, 2016). Public and institutional awareness of $\mathrm{N}$-related benefits and threats have the potential to provide an essential basis for developing concrete actions and enhancing the effectiveness of future policies (REAY et al., 2011).

Nitrogen Use Efficiency (NUE) is a concept that encompasses the fundamentals of crop nutrition and good practices for efficient fertilizer use (CASARIN; STIPP, 2013). The NUE estimates have been widely used as an indicator to assess progress in nutrient management (BRENTRUP; PALLIERE, 2010; SUTTON et al., 2013; NORTON; DAVIDSON; ROBERTS, 2015). Improvements in the NUE can contribute to achieving best $\mathrm{N}$ management practices, providing the best combination of economic, social, and environmental performance (OENEMA et al., 2015). In this way, NUE is an important metric to evaluate the options to improve the agricultural production in order to reach the SDGs (ZHANG et al., 2015).

NUE can be estimated by different ways and there is no uniform methodology to be used, although it is widely taken as an indicator of agricultural efficiency. NUE calculation is done 
TÔSTO, K. L., PACHECO, F. S., GOMES, L., MIRANDA, M., OLIVEIRA, S. M. L., PESSI, D. D., COX, C., OMETTO, J. P. H. B.

\section{NITROGEN USE EFFICIENCY: A LOCAL AND REGIONAL APPROACH FOR BRAZILIAN AGRICULTURE}

depending on the purpose of the analysis and data availability (OENEMA et al., 2015). NUE is an important tool to help decision making at different levels and it can be calculated for different systems and at different spatial (national scale at the farm level) and temporal scales (ZHANG et al., 2015).

In this work, NUE was analyzed on a national scale and compared with NUE of agricultural production systems in an important watershed of the Upper Pantanal. From the spatial analysis of nitrogen fertilizer use and $\mathrm{N}$ removal by agricultural production in Brazil, NUE was estimated for the Brazilian states (regional scale), and with local data from farmers and institutions, NUE was estimated for the agricultural soils in the Rio Vermelho watershed (local scale). The hypothesis is that, although the Rio Vermelho watershed presents environmental risks related to the fertilizer use, the local scenario is still better than several agricultural regions in Brazil, suggesting that public policies aiming to improve NUE should take the agricultural systems used in different regions of the country into account.

\section{MATERIALS AND METHODS}

\subsection{Study site}

Brazil (Figure 1) is one of the world's leading suppliers of agricultural products and will play an important role in meeting the demands in both the domestic and international markets (FAO, 2017). Within the country, the main crops, in terms of productive area, are soybean (39\%), maize (21\%) and sugarcane (13\%) (IBGE, 2017a). The country has shown substantial economic growth in both agriculture and food processing, ensuring a leading position in the international trade (HUBBARD; ALVIM; GARROD, 2017; GASQUES; BACCHI; BASTOS, 2018).

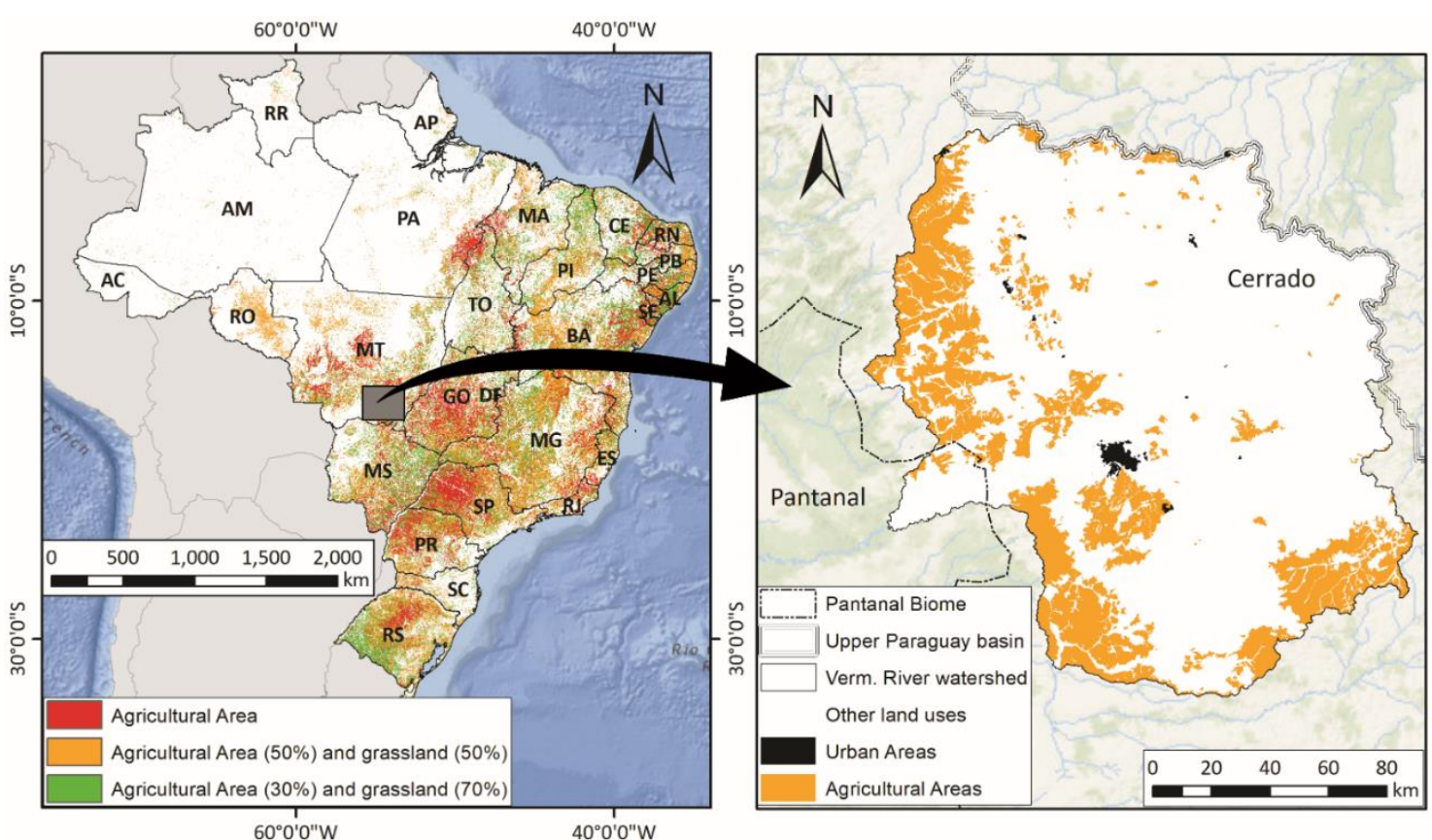

Figure 1- Distribution of agricultural crops in Brazil. On the right is highlighted the Vermelho River watershed (MT).

The Cerrado accounts for about $70 \%$ of Brazil's agricultural production, contributing for much of the country's cotton, soybeans, beef and sugarcane production (GOMES et al., 2019). This biome is a biodiversity hotspot due to its high rate of endemism and the high degree of habitat threat, mainly due to recent land use changes (STRASSBURG et al., 2017). The Cerrado has already lost more than $40 \%$ ( $88 \mathrm{Mha}$ ) of its native cover to meet the demands for agricultural 
TÔSTO, K. L., PACHECO, F. S., GOMES, L., MIRANDA, M., OLIVEIRA, S. M. L., PESSI, D. D., COX, C., OMETTO, J. P. H. B.

\section{NITROGEN USE EFFICIENCY: A LOCAL AND REGIONAL APPROACH FOR BRAZILIAN AGRICULTURE}

products, (LAPOLA et al., 2013; STRASSBURG et al., 2014; LAHSEN; BUSTAMANTE; DALLA-NORA, 2016). In addition, about $80 \%$ of the area of remaining natural vegetation is suitable for soybean cultivation and $70 \%$ is proper for growing sugarcane, crops in which demand is expected to increase markedly in the coming decades (STRASSBURG et al., 2014, 2017). For instance, areas under annual crops have already been enlarged by 25 million hectares over the last 15 years, with more than $60 \%$ in the Brazilian Midwest (GASQUES et al., 2016).

The Vermelho River watershed (Figure 1), considered for local scale analysis in this work, is located in Mato Grosso State (MT) and represents an important nucleus of agricultural production area in the Brazilian Cerrado. Rondonópolis is the main municipality inside the watershed and the second largest economy in Mato Grosso state and is among the 100 largest economies in Brazil, with a GDP of R\$ 9.4 billion. Agribusiness is one of the main economic activities and the "driving force" for many other secondary sectors of the local economy (IBGE, 2018).

In the Vermelho River watershed, $95 \%$ of agricultural production is represented by three crops: soybean (63\%), maize (22\%) and cotton (10\%) (IBGE, 2017a). Soybeans are grown during the beginning of the rainy season (October to January) followed mainly by a second maize or cotton crop. In the region, the maize and cotton production as second crop represents about $60 \%$ to $70 \%$ and $30 \%$ to $40 \%$, respectively (FMT, personal communication).

The Vermelho River (also known as São Lourenço river) is one of the main rivers that feeds the Pantanal plain and fundamental for the maintenance of the Pantanal water regime (LOVERDE-OLIVEIRA; NASCIMENTO, 2004). The Pantanal has great ecological value, being considered a National Patrimony, an area of international importance by the Convention of Wetlands (Ramsar) and a UNESCO World Heritage (FERREIRA, 2013; ANA, 2017).

Inadequate soil management practices associated with local conditions have favored the occurrence of erosive processes, leading to soil nutrients losses and degradation of the Cerrado lands productivity (GOMES et al., 2019). This inadequate management has led to an increase in the contribution of sediments and nutrients to the Pantanal region, reducing its support capacity, resilience and ecosystem services provision, such as nutrients retention and recycling, water purification, fish stocks, among others (BERGIER, 2013; GALDINO; GREGO, 2014; MORESCHI; PAES; CALHEIROS, 2015). Despite its current good state of conservation compared to other large freshwater ecosystems in the world, the Pantanal has been changing rapidly, and measures are needed in order to adopt good practices that minimize such impacts (INSTITUTO SOS PANTANAL; WWF-BRASIL, 2015).

\subsection{Method to evaluate Nitrogen Use Efficiency}

In this work, NUE was based on the principle of Partial Balance of Nutrients (PNB), a recommended method by the International Plant Nutrition Institute (IPNI), usually expressed as a nutrient removal rate (SNYDER, 2009). The NUE is defined by the ratio between the $\mathrm{N}$ outflows and inputs in the agro-systems, expressed as the mass fraction $\left(\mathrm{kg} \mathrm{kg}^{-1}\right)$.

A NUE value near 1 can lead to misinterpretation because it suggests that soil fertility will be sustainable in the long term. However, since the balance calculation is a partial estimate and the removal of nutrients by processes such as erosion and leaching are generally not included, a NUE value of 1 is not used as an indicator of soil fertility sustainability, particularly in regions with both low fertility soils and low inputs and production (MATHUR; GOEL, 2017). Values well below 1 , where nutrient intake greatly exceed nutrient removal, suggest avoidable losses of nutrients to the environment and therefore the need to improve NUE (SNYDER; BRUULSEMA, 2007), being the optimal value of NUE to be reached depending on the production system and the soil characteristics. NUE greater than 1 means that more nutrients are removed with the crop than they are applied by fertilizer, a situation equivalent to "soil nutrient mining". This 
TÔSTO, K. L., PACHECO, F. S., GOMES, L., MIRANDA, M., OLIVEIRA, S. M. L., PESSI, D. D., COX, C., OMETTO, J. P. H. B.

\section{NITROGEN USE EFFICIENCY: A LOCAL AND REGIONAL APPROACH FOR BRAZILIAN AGRICULTURE}

situation may be desired if soil nutrient levels are higher than recommended. However, in cases where the nutrient concentration in the soil is at or below the recommended levels, NUE greater than 1 should be considered unsustainable (BRENTRUP; PALLIERE, 2010).

NUE calculated using PNB is expressed by the following equation:

$$
N U E_{P N B}=N C / F
$$

In which NC is the nitrogen content of the portion harvested from the crop and $F$ is the amount of nitrogen applied. In this calculation, the Biological Fixation of Nitrogen (BNF, biological fertilization) is also considered as part of the applied nutrient.

\subsection{Data for the calculation of NUE on a national scale}

The $\mathrm{N}$ outputs represent the amount of this nutrient that is removed through the harvested products (NC, $\mathrm{kgN} \mathrm{ha}^{-1} \mathrm{yr}^{-1}$ ). To calculate these values for the Brazilian states the extension of cultivated areas (MAPBIOMAS, 2018) and productivity of Brazilian agriculture in each state for the year 2010 were used (IBGE, 2017a), together with estimates of the $\mathrm{N}$ content for each agricultural product, according to the United Nations Food and Agriculture Organization (FAO) and IPNI.

For the $\mathrm{N}$ inputs in the agricultural systems, it was considered the addition of synthetic fertilizers in the crops as well as the input by FBN ( $\left.\mathrm{kgN} \mathrm{ha}^{-1} \mathrm{yr}^{-1}\right)$. Fertilizer consumption data was extracted from IBGE's
SIDRA database (IBGE, 2017b). The contribution of BNF to $\mathrm{N}$ input in agricultural soils was obtained from the average rates available in the literature for the main crops in Brazil.

In general, $\mathrm{N}$ inputs and outputs vary in space and time in real conditions due to the great diversity of physical elements of the landscape, soil variety, and climatic conditions. However, since most of the available input and output data for $\mathrm{N}$ are annual, generalizations were made in the present work to calculate NUE in Brazilian territory.

\subsection{Data for the calculation of the NUE in watershed scale}

The Vermelho River watershed was used to investigate changes of NUE in space and over time at a local scale. The parameters of the equation (inputs and outputs of $\mathrm{N}$ ) refer to the average agricultural productivity of the study area (IBGE, 2017a). These data (Table 1) were extracted from the literature and provided by the Mato Grosso Foundation, an important private research institution, which works with the state's farmers to promote agriculture development (FMT, personal communication).

In order to identify areas destined to the agricultural production in local scale, data of land use and land cover (MAPBIOMAS, 2018) were used and compared with local maps generated by the Socio-environmental Institute of the Upper Paraguay Basin in partnership with WWF-Brazil (INSTITUTO SOS PANTANAL; WWF-BRASIL, 2015).

Table 1 - Nitrogen inputs and outputs $\left(\mathrm{N} ; \mathrm{kg} \mathrm{N} \mathrm{ha}^{-1} \mathrm{yr}^{-1}\right)$ in the Vermelho River watershed.

\begin{tabular}{|c|c|c|c|}
\hline Nitrogen Fluxes & Cultivo Agrícola & kg N ha ${ }^{-1}$ ano $^{-1}$ & Reference \\
\hline \multirow{5}{*}{$\mathrm{N}$ input - Mineral fertilization } & Soybean & 0 & Personal communication \\
\hline & Maize & 80 & Personal communication \\
\hline & & & $\begin{array}{l}\text { Alves et al., 2006; Carvalho et } \\
\text { al., 2009; Carvalho; Bernardi, }\end{array}$ \\
\hline & Cotton & $124.8 \pm 19.4$ & 2005; Cruvinel et al., 2011; \\
\hline & & & $\begin{array}{c}\text { Kaneko et al., 2013; Motomiya } \\
\text { et al., } 2011\end{array}$ \\
\hline
\end{tabular}


TÔSTO, K. L., PACHECO, F. S., GOMES, L., MIRANDA, M., OLIVEIRA, S. M. L., PESSI, D. D., COX, C., OMETTO, J. P. H. B.

NITROGEN USE EFFICIENCY: A LOCAL AND REGIONAL APPROACH FOR BRAZILIAN AGRICULTURE

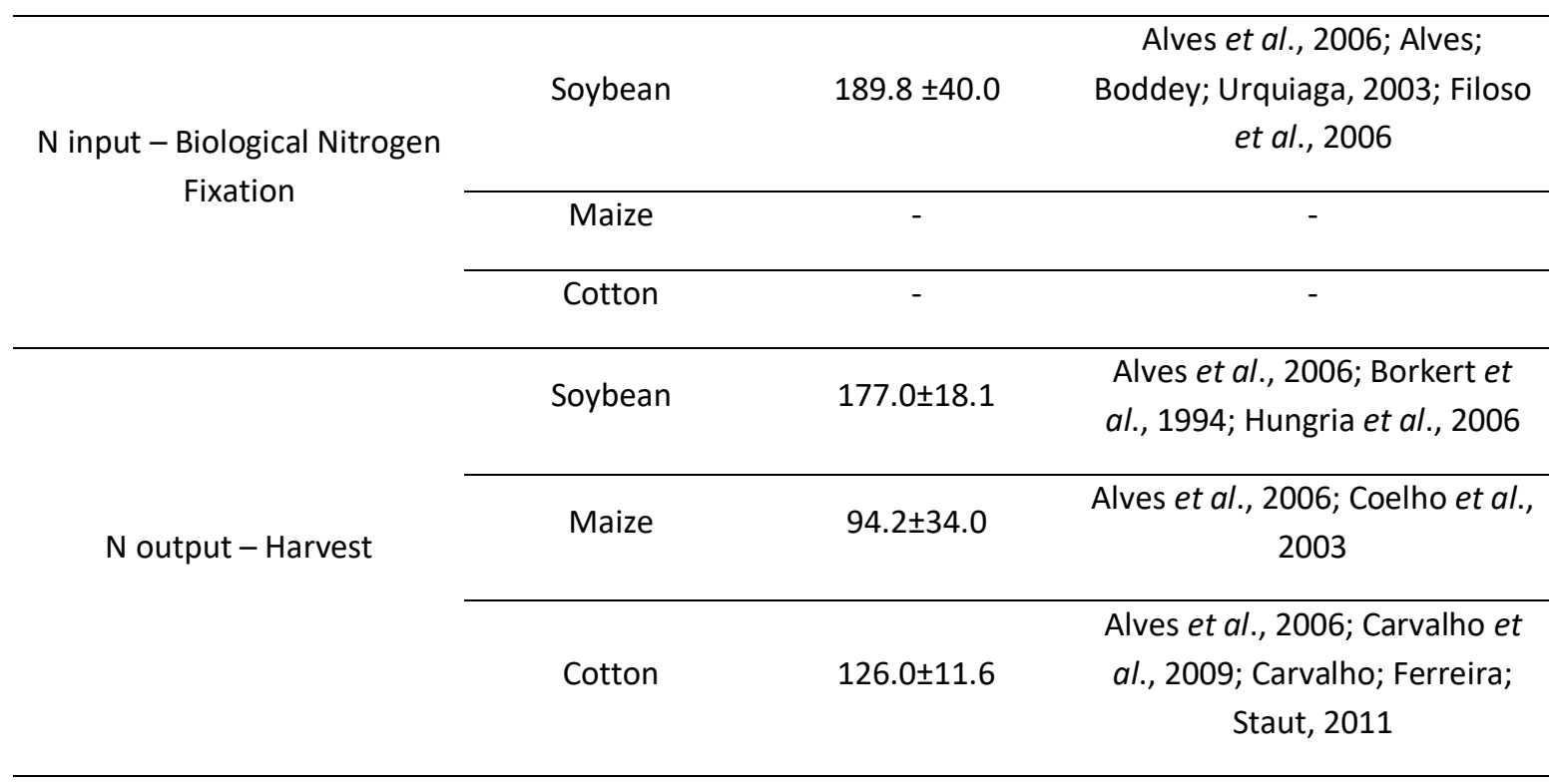

\subsection{Analysis and presentation of NUE data}

The NUE results for the Brazilian states and the Vermelho River watershed are presented in a two-dimensional diagram, which relates the $\mathrm{N}$ outputs (x-axis) and $\mathrm{N}$-surplus in the system (the difference between inputs and outputs of $\mathrm{N}$, $y$-axis). Values of NUE are expressed as the mass fraction $\left(\mathrm{kg} \mathrm{kg}^{-1}\right)$ and the inputs and outputs as $\mathrm{kg}$ $\mathrm{ha}^{-1} \mathrm{yr}^{-1}$, as suggested by the European Union Panel of Nitrogen Experts (OENEMA et al., 2015).

The reference lines represent the upper and lower limits for NUE (0.5 to 0.9), demonstrating desirable management. The lower value of 0.5 used in this study is considered a viable mean value for practices of many cropping systems. The target limit of more than 0.9 is suggested because NUE of 1 may represent soil mining, since the removal of nutrients by processes, such as erosion and leaching, is not included in this approach, as mentioned above. The exact position of the reference lines is experimental and should be adjusted in several cases as the baselines. Target values depend on the type of farming systems (and food systems) as well as on the environmental conditions (i.e., soils, geomorphology, and climate). The definition of these target values is therefore a task involving science, practice, and policy domains (OENEMA et al., 2015). The desirable minimum production line represents the average of the current $\mathrm{N}$ production system throughout Latin America (60 kg N ha-1).

The data were spatially represented through a Geographic Information System (ESRI ArcMap 10.4.1). At the national scale, land use maps were decomposed into a regular cell grid of $400 \times 400$ meters and the percentages of each class were computed for each cell. The same was done with a regular grid of $30 \times 30$ meters for the study in the Vermelho River watershed. Since the "Annual Crops" class (original maps) does not separate the distribution of soybean, maize, and cotton crops, data were extracted from the official surveys of Municipal Agricultural Production (IBGE, 2017a). The area of each crop was then equally distributed in the Agriculture class.

\section{RESULTS AND DISCUSSION}

\subsection{NUE in the agricultural areas of Brazil}

The spatial distribution of NUE calculated for agricultural areas in Brazil is shown in Figure 2. Very low values (less than 0.5) represent the low efficiency in $\mathrm{N}$ use and are observed in parts of the northeast - states of Pernambuco (PE), Paraíba (PB), and Alagoas (AL) - and southeast - state of Espírito Santo (ES). In such states, the $\mathrm{N}$ inputs in both the system through FBN and mineral fertilization are more than twice as high as the total exported by the 


\section{NITROGEN USE EFFICIENCY: A LOCAL AND REGIONAL APPROACH FOR BRAZILIAN AGRICULTURE}

harvest. The sugarcane, beans, and corn crops predominate in the northeastern states, which together represent 80,72 and $88 \%$ of the crop area of $\mathrm{PE}, \mathrm{PB}$ and $\mathrm{AL}$, respectively. In Espírito Santo State, coffee cultivation occupies $80 \%$ of the agricultural area, followed by the cultivation of sugarcane, which represents $12 \%$ (IBGE, 2017a). Mineral fertilization represents the largest $\mathrm{N}$ input in the agricultural soils of these states, except for Paraíba State, in which the entry of $\mathrm{N}$ by biological and mineral fertilization are equivalent. In Espírito Santo State, about 90\% of the $\mathrm{N}$ comes from mineral fertilization. These results indicate that $\mathrm{N}$ management in these areas has been inefficient since the removal through agricultural products does not justify the contribution of $\mathrm{N}$ to agriculture.

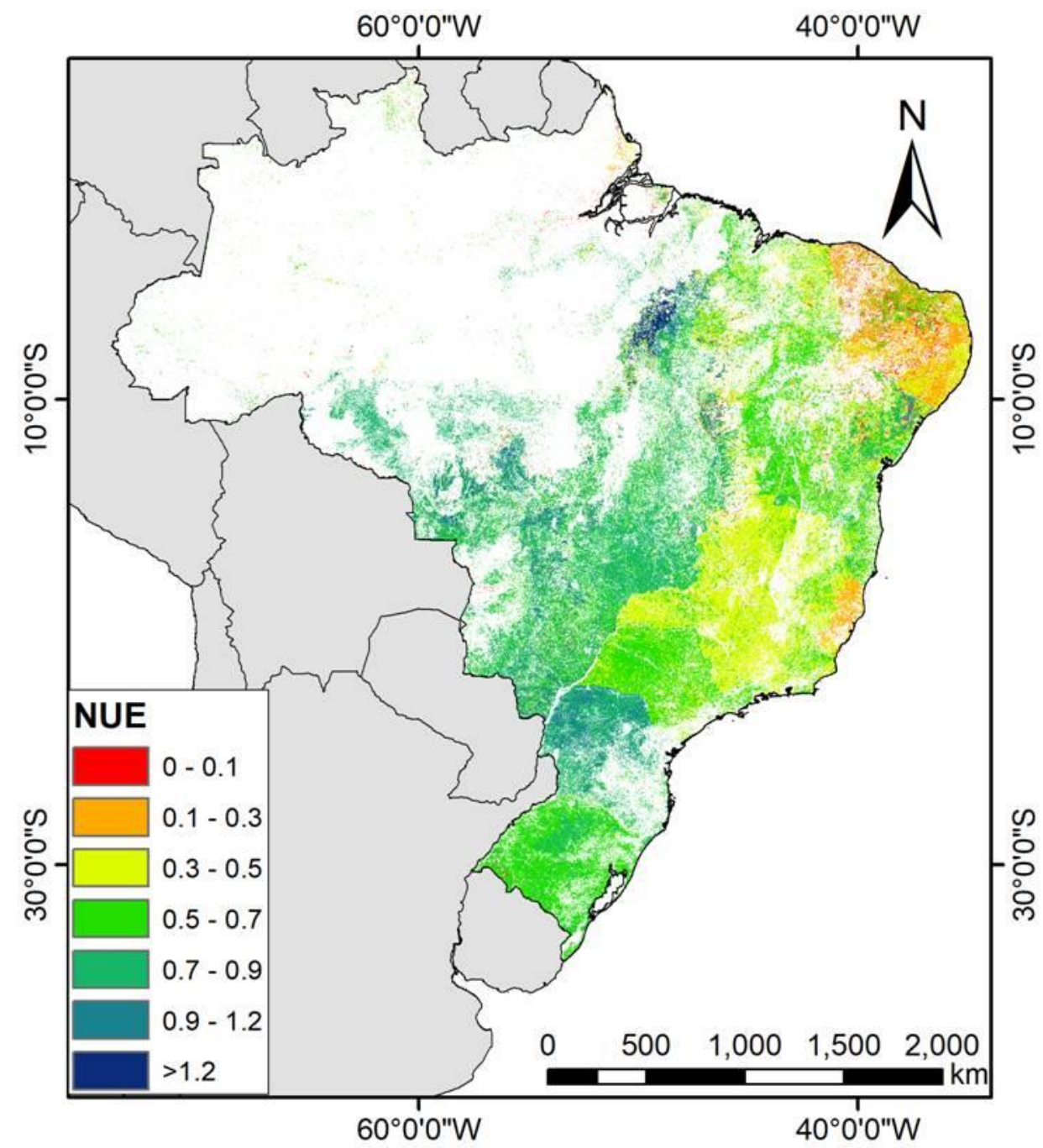

Figure 2 - Spatially explicit data of NUE in Brazil.

On the other hand, very high values of NUE (above 0.9) indicate that the $\mathrm{N}$ outputs of the system exceed the replacement of this nutrient in the soil, which can lead to $\mathrm{N}$ mining, agricultural soil degradation and productive capacity losses. For these soils, nutrient replacement should be carefully considered. The risk of $\mathrm{N}$ mineralization of soils is high for states of great relevance to Brazilian agricultural production, such as Mato Grosso State and Mato Grosso do Sul State (MS). In these states, N inputs through biological fixation represent more than $75 \%$ of total $\mathrm{N}$ added to the environment, highlighting, in these areas, the importance of 
TÔSTO, K. L., PACHECO, F. S., GOMES, L., MIRANDA, M., OLIVEIRA, S. M. L., PESSI, D. D., COX, C., OMETTO, J. P. H. B.

\section{NITROGEN USE EFFICIENCY: A LOCAL AND REGIONAL APPROACH FOR BRAZILIAN AGRICULTURE}

soybean cultivation. Others important productive areas located in the Cerrado biome present the same situation, in which $\mathrm{N}$ extraction exceeds the replacement of this nutrient, leading to economic and environmental losses, as observed by Gomes et al. (2019).

3.2 NUE in the Vermelho River watershed Upper Paraguay Basin.

The Vermelho River watershed presents an NUE with values close to the desired maximum considered for Brazil (Table 2). Between 2000 and 2015, the average $\mathrm{N}$ surplus in soils was relatively low (about $14 \mathrm{~kg} \mathrm{ha}^{-1}$ ). As expected, BNF constitutes the main input of $\mathrm{N}$ in agro-systems (77\%), while the addition of mineral fertilizer represents $23 \%$ of the inputs. No relevant changes are identified for any of the parameters observed over time, although it was possible to observe a tendency to decrease the value of NUE for a lower risk of $\mathrm{N}$ mining of the soil.

Land use changes in the Vermelho River watershed were intense between 2000 and 2015. During this period, natural vegetation areas decreased by $9.1 \%\left(10,153 \mathrm{~km}^{2}\right)$ while agriculture and pasture increased by $9.2 \%\left(3,663 \mathrm{~km}^{2}\right)$ and $8.8 \%\left(6,652 \mathrm{~km}^{2}\right)$, respectively. The increase in the agricultural area of the basin was mainly due to the expansion of soybean and corn crops.

Table 2: Time evaluation of N inputs, outflows and surpluses and NUE results for the Vermelho River watershed in the years 2000, 2005, 2010 and 2015.

\begin{tabular}{lcccc}
\hline \multicolumn{1}{c}{ Year } & 2000 & 2005 & 2010 & 2015 \\
\hline N-inputs $\left(\mathrm{kg} \mathrm{ha}^{-1}\right)$ & 158.6 & 164.0 & 158.3 & 158.7 \\
N-outputs $\left(\mathrm{kg} \mathrm{ha}^{-1}\right)$ & 145.2 & 150.6 & 144.6 & 143.0 \\
Surplus $\left(\mathrm{kg} \mathrm{ha}^{-1}\right)$ & 13.4 & 13.5 & 13.7 & 15.7 \\
NUE $\left(\mathrm{kg} \mathrm{kg}^{-1}\right)$ & 0.92 & 0.92 & 0.91 & 0.90 \\
\hline
\end{tabular}

\subsection{Integrated vision of NUE at different scales of analysis}

The NUE approach presented in this paper is easily suitable to different food production and consumption systems and to a number of scales. The indicator is especially useful for monitoring changes in efficiency both from small farms to a national level to detect the effects of technical progress and policy interventions on the use of $\mathrm{N}$. Consider limits to NUE values may be a risky simplification for a complex production system, as it is the case of Brazil. However, the use of a standard method of simple analysis at multiple scales can become an effective tool as detailed information is not required for analysis. It allows a comparison between different regions with different production systems and it is also easy to use by decision makers that may evaluate measures to improve NUE in critical regions. Much of the Brazilian territory presents NUE within the desirable limits (between 0.5 and 0.9, Figure 3). These regions are mainly concentrated in the Brazilian Cerrado and the southern region of Brazil. It should be emphasized that these conditions can be changed if there is an intensification of the use of fertilizers in the Brazilian territory, as expected in future projections of the consumption of this nutrient (MARIN et al., 2016). 
TÔSTO, K. L., PACHECO, F. S., GOMES, L., MIRANDA, M., OLIVEIRA, S. M. L., PESSI, D. D., COX, C., OMETTO, J. P. H. B.

\section{NITROGEN USE EFFICIENCY: A LOCAL AND REGIONAL APPROACH FOR BRAZILIAN AGRICULTURE}

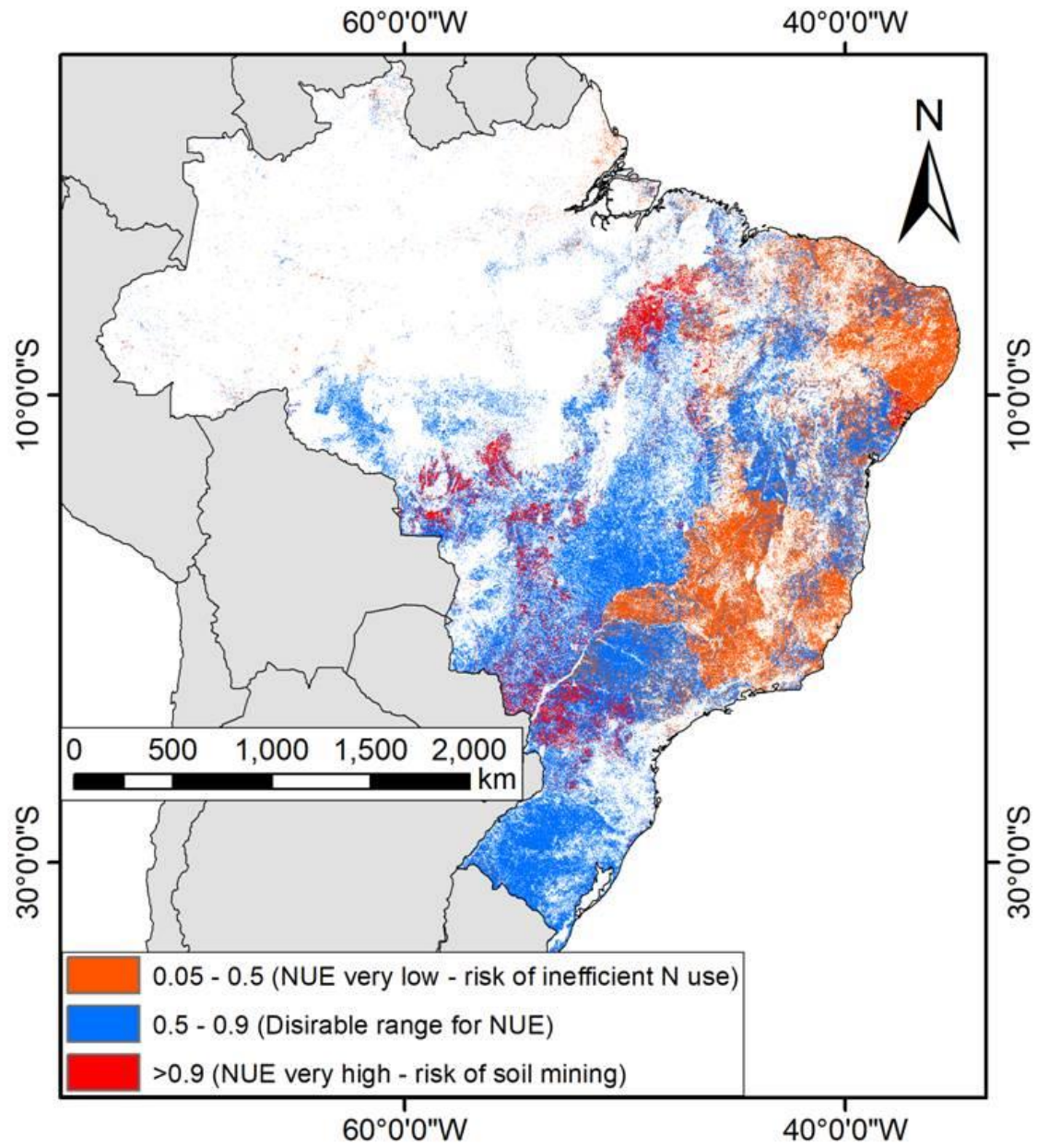

Figure 3 - Spatially explicit data from NUE in Brazil, considering three categories and potential environmental risks: NUE very low (risk of inefficient use of $N$ ), NUE between 0.5 and 0.9 (it comprises the desired interval for proper $\mathrm{N}$ management) and NUE higher than 0.9 (soil $\mathrm{N}$ mining risk).

In addition, there are representative regions of Cerrado with high values of NUE where production systems use management practices that cause great risks of both degradation and loss of soil productivity. Only five from the 26 Brazilian states and the Federal District were within the desirable average limits considered by NUE and minimum production of $\mathrm{N}$ per hectare (states of Bahia (BA), São Paulo (SP), Santa Catarina (SC), Rio Grande do Sul (RS) and Goiás (GO), Figure 4). Although the states with the highest agricultural production are of undoubted importance to the Brazilian economy, Mato Grosso, Mato Grosso do Sul and Paraná (PR) present an average of NUE above desirable value, being necessary measures of adequacy of the productive system, such as the application of the management method of 4R Nutrient Stewardship, which means right source of nutrients, in the right dose at the right time and at the right place, to avoid soil $\mathrm{N}$ mining (CASARIN; STIPP, 2013).

Although some states present adequate NUE such as Piauí (PI), Roraima (RR), and Rondônia (RO), the amount produced per hectare is considered low in comparison to the rest of Brazil. This represents a low productive capacity of the region dedicated to agricultural activities, which can encourage the expansion of agricultural areas to natural regions to increase food production. On the other hand, the other Brazilian states, on average, present NUE with inadequate values and the current need for 
TÔSTO, K. L., PACHECO, F. S., GOMES, L., MIRANDA, M., OLIVEIRA, S. M. L., PESSI, D. D., COX, C., OMETTO, J. P. H. B.

\section{NITROGEN USE EFFICIENCY: A LOCAL AND REGIONAL APPROACH FOR BRAZILIAN AGRICULTURE}

adequacy in agricultural management to guarantee a sustainable production system.

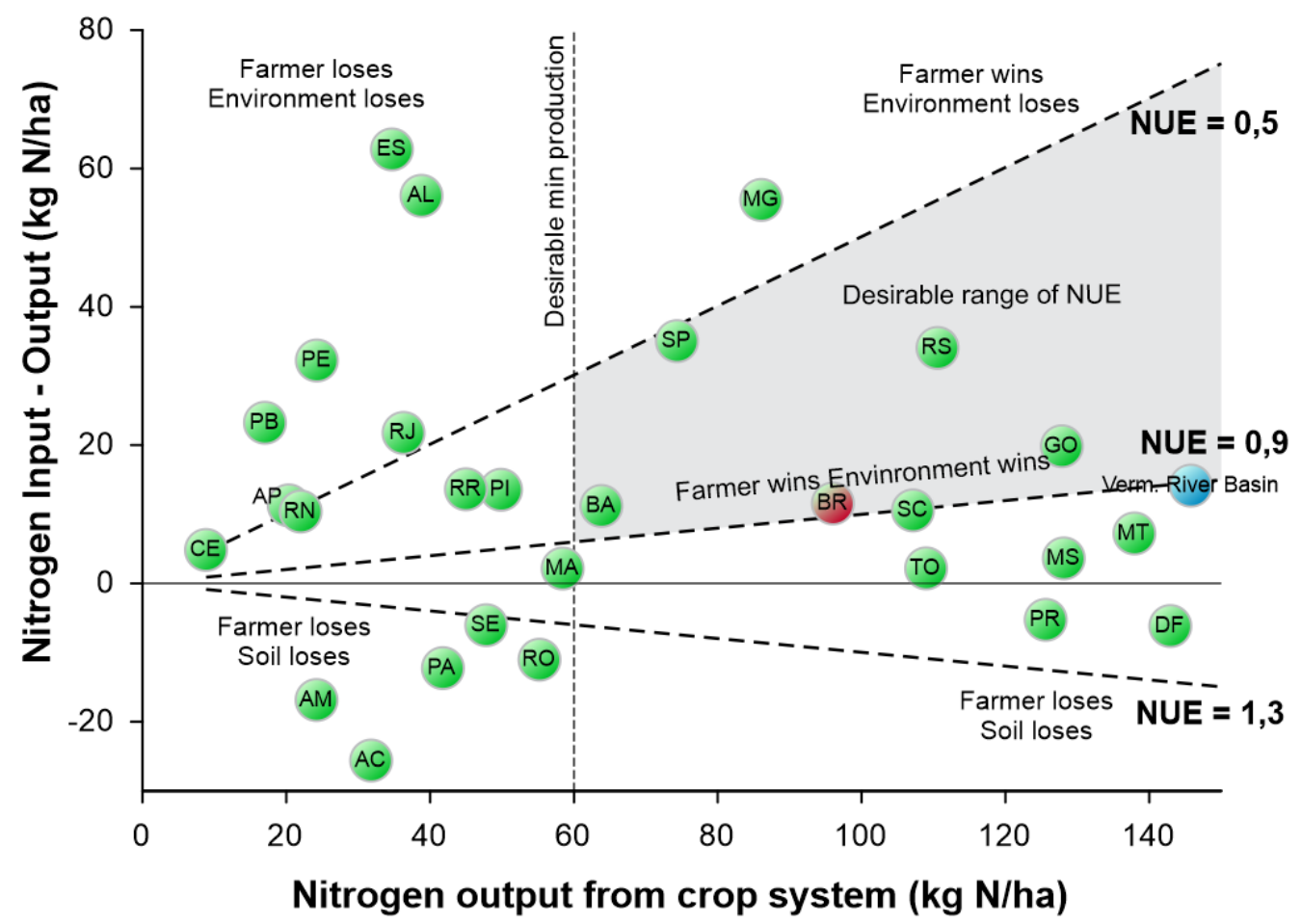

Figure 4 - Nitrogen Use Efficiency (NUE) in the Vermelho River watershed and in the Brazilian states.

Facing the national framework, the Vermelho River watershed presents the NUE for agricultural systems close to 0.9. The NUE values for the cropping system are slightly above the target range, meaning a risk of soil mining. To ensure a more sustainable system and prevent soil degradation and nitrogen mining, it is possible to propose a more sustainable practice preserving both the soil and the environmental characteristics, thus improving the efficiency in the use of fertilizers. An option to improve the production system is to increase NUE's desirable upper limit by further development of agricultural practices to prevent $\mathrm{N}$ loss through leaching, erosion, and emission. Compared with other regions of Brazil, the NUE of the Vermelho River watershed is close to the values found for the whole Midwest region (Federal District (DF), and states of Mato Grosso, Mato Grosso do Sul and Goiás) and also the Brazilian average of NUE $(0,89)$.

The efficient use of $\mathrm{N}$ in agriculture does not necessarily represent the sustainability of the use of this nutrient, the latter being a much broader concept (OENEMA et al., 2015). The purpose of using NUE as an indicator in agrosystems is to evaluate the relationships between $\mathrm{N}$ inputs and outputs in agricultural soils, indicating possible limitations or excesses, which are related to losses in productivity and/or increase in emissions of nitrogen compounds to atmosphere and water bodies. This tool can subsidize the identification and planning of necessary actions to promote changes in the use of $\mathrm{N}$ in agricultural systems at different scales.

Other data can be used in the interpretation of NUE to adequately investigate agricultural sustainability (NORTON; DAVIDSON; ROBERTS, 2015). In principle, all inputs and outputs of $\mathrm{N}$ must be incorporated into the calculation of NUE, however, in practice, accurate information can limit this approach. In addition to mineral and biological fertilization, other entrances of $\mathrm{N}$ into the agro-systems may play an important role, such as atmospheric deposition and animal fertilizers. As agricultural systems are 
TÔSTO, K. L., PACHECO, F. S., GOMES, L., MIRANDA, M., OLIVEIRA, S. M. L., PESSI, D. D., COX, C., OMETTO, J. P. H. B.

\section{NITROGEN USE EFFICIENCY: A LOCAL AND REGIONAL APPROACH FOR BRAZILIAN AGRICULTURE}

not closed, losses of $\mathrm{N}$ to the atmosphere and water bodies characterize other outputs of this

\section{FINAL CONSIDERATIONS}

The results obtained in this work illustrate the heterogeneity of $\mathrm{N}$ use efficiency in the agricultural areas of Brazil. Although some places exhibit satisfactory NUE values according to defined parameters (states of São Paulo, Bahia, Rio Grande do Sul and Goiás), most of the Brazilian territory present more extreme values, with areas subject to $\mathrm{N}$ mining (part of the Midwest, South and North region) and others in which $\mathrm{N}$ incorporated in agriculture is not effectively transformed into harvested products (much of the Northeast and Southeast of Brazil).

Brazil has great relevance in the world scenario and requires good practices of nutrient management to maintain productivity associated with environmental and social sustainability. Thus, the efficiency improvement of nutrient use, especially in the areas identified by this work, should be considered as a fundamental goal to achieve the SDGs, due to the innumerable future challenges to produce more food with less impact. Policies implementation or other mechanisms to achieve both SDGs and greater food security should consider faster production development and wider adoption of new technologies.

Despite the generalizations required due to the represented scales and data availability, the spatial analysis of NUE performed for the study area is unprecedented and it allows a better understanding of the recent changes related with agricultural practices in the $\mathrm{N}$ cycle in Brazil. Although NUE does not consider all these inflows and outflows, this indicator is considered feasible for the analysis performed in the present work. Furthermore, since it is a common worldwide used indicator, NUE facilitates better monitoring and evaluation of public policy performance applied in several regions with different environmental characteristics.

\section{ACKNOWLEDGEMENT}

nutrient beyond those estimated from the harvested products.

The present study was developed with the support of Coordenação de Aperfeiçoamento de Pessoal de Nível Superior - Brasil (CAPES) Finance Code 001 and the Towards the Establishment of an International Nitrogen Management System (INMS) Project. The authors are grateful for the collaboration provided by the Global Program of Action of the United Nations Environment Program (GPA / UNEP), Global Partnership on Nutrition Management (GPNM), Mato Grosso Foundation and International Plant Nutrition Institute.

\section{REFERENCES}

ALVES, B. J. R.; BODDEY, R. M.; URQUIAGA, S. The success of BNF in soybean in Brazil. Plant and Soil, v. 252 , n. 1 , p. $1-9,2003$.

ALVES, B. J. R.; ZOTARELLI, L.; FERNANDES, F. M.; HECKLER, J. C.; MACEDO, R. A. T. de; BODDEY, R. M.; JANTALIA, C. P.; URQUIAGA, S. Fixação biológica de nitrogênio e fertilizantes nitrogenados no balanço de nitrogênio em soja, milho e algodão. Pesquisa Agropecuária Brasileira, v. 41, n. 3, p. 449-456, 2006.

ANA. Plano de Recursos Hídricos da Região Hidrográfica do Paraguai - PRH Paraguai, Produto Pacial PP-02 - Diagnóstico Consolidado da Região Hidrográfica do Rio Paraguai. Brasília.: Agência Nacional de Águas-SPR/Engecorps Engenharia S.A., 2017.

BERGIER, I. Effects of Highland Land-Use over Lowlands of the Brazilian Pantanal. Science of The Total Environment, v. 463-464, p. 1060-1066, 2013.

BILLEN, G.; SILVESTRE, M.; GRIZZETTI, B.; LEIP, A.; GARNIER, J.; VOSS, M.; HOWARTH, R.; BOURAOUI, F.; LEPISTÖ, A.; KORTELAINEN, P.; JOHNES, P.; CURTIS, C.; HUMBORG, C.; SMEDBERG, E.; KASTE, $\varnothing$;; GANESHRAM, R.; BEUSEN, A.; LANCELOT, C. Nitrogen flows from European regional watersheds to coastal marine waters. In: SUTTON, M. A.; HOWARD, C. M.; 
TÔSTO, K. L., PACHECO, F. S., GOMES, L., MIRANDA, M., OLIVEIRA, S. M. L., PESSI, D. D., COX, C., OMETTO, J. P. H. B.

\section{NITROGEN USE EFFICIENCY: A LOCAL AND REGIONAL APPROACH FOR BRAZILIAN AGRICULTURE}

ERISMAN, J. W.; BILLEN, G.; BLEEKER, A.; GRENNFELT, P.; van GRINSVEN, H.; GRIZZETTI, B. The European Nitrogen Assessment. Cambridge: Cambridge University Press, 2011. cap. 13, p. 271-297.

BORKERT, C. M.; YORINORI, J. T.; CORRÊAFERREIRA, B. S.; ALMEIDA, Á. M. R.; FERREIRA, L. P.; SFREDO, G. J. Seja o doutor da sua soja. Informações Agronômicas Arquivo do Agrônomo, Piracicaba, v. 5, n.66, p. 1-16, 1994.

BRENTRUP, F.; PALLIERE, C. Nitrogen Use Efficiency as an Agro-Environmental Indicator. In: OECD WORKSHOP: AGRI-ENVIRONMENTAL INDICATORS: LESSONS LEARNT AND FUTURE DIRECTIONS. 2010. Leysin, Suíça: 23-26 Março de 2010, p. 1 - 9.

CARVALHO, M. da C. S.; BERNARDI, A. C. de C. Resposta do algodoeiro à adubação potássica. Informações Agronômicas - Encarte, Piracicaba, n. 107, p. 1-10, 2004.

CARVALHO, M. da C. S.; FERREIRA, G. B.; STAUT, L. A. Nutrição, calagem e adubação do algodoeiro. In: FREIRE, E. C. (Ed.). Algodão no Cerrado do Brasil. 2a ed. Brasília, DF: Embrapa Agropecuária Oeste, 2011. p. 677-752.

CARVALHO, M. da C. S.; FERREIRA, A. C. de B.; LAMAS, F.; PICCOLO, M. de C. Manejo de fontes alternativas de fertilizantes nitrogenados na sucessão braquiária-algodão em sistema plantio direto no Cerrado - Safra 2007/2008. In: VII Congresso Brasileiro do Algodão Sustentabilidade da cotinicultura Brasileira e Expansão dos Mercados, Foz do Iguaçu, PR: Embrapa Algodão, 2009.

CASARIN, V.; STIPP, S. R. Quatro medidas corretas que levam ao uso eficiente dos fertilizantes. Informações Agronômicas, Piracicaba, n.142, p. 14-20, 2013.

COELHO, A. M.; CRUZ, J. C.; ALEXANDRE, I.; FILHO, P. Rendimento do milho no Brasil: chegamos ao máximo? Informações Agronômicas, Piracicaba, n.101, p. 1-12, 2003.

CRUVINEL, Ê. B. F.; BUSTAMANTE, M. M. da C.; KOZOVITS, A. R.; ZEPP, R. G. Soil emissions of NO,
$\mathrm{N} 2 \mathrm{O}$ and $\mathrm{CO} 2$ from croplands in the savanna region of central Brazil. Agriculture, Ecosystems \& Environment, v. 144, n. 1, p. 29-40, 2011.

DAVIDSON, E. A.; NIFONG, R. L.; FERGUSON, R. B.; PALM, C.; OSMOND, D. L.; BARON, J. S. Nutrients in the nexus. Journal of Environmental Studies and Sciences, v. 6, n. 1, p. 25-38, 2016.

DOBERMANN, A. Looking forward to 2030: Nitrogen and the Sustainable Development Goals. In: INTERNATIONAL NITROGEN INITIATIVE CONFERENCE: "Solutions to improve nitrogen use efficiency for the world", Melbourne, Australia: Anais... 2016 p. 4-8.

ERISMAN, J. W.; GALLOWAY, J. N.; DICE, N. B.; SUTTON, M. A.; BLEEKER, A.; GRIZZETTI; B.; LEACH, A. M.; VRIES, W. de; ESTATE, B.; ESTATE, B. Nitrogen: Too much of a vital resource. Zeist, The Netherlands: Science Brief - WWF The Netherlands, 2015.

FAO. World fertilizer trends and outlook to 2020 Summary Report. Rome, Food and Agriculture Organization of the United Nations, 2017.

FERREIRA, A. B. de B. Pantanal Mato-Grossense: considerações sobre a proteção constitucional para um desenvolvimento econômico sustentável. Interações, Campo Grande, v. 14(1), p. 11-20, 2013.

FILOSO, S.; MARTINELLI, L. A.; HOWARTH, R. W.; BOYER, E. W.; DENTENER, F. Human activities changing the nitrogen cycle in Brazil. Biogeochemistry, v. 79, n. 1-2, p. 61-89, 2006.

FOWLER, D.; COYLE, M.; SKIBA, U.; SUTTON, M. A.; CAPE, J. N.; REIS, S.; SHEPPARD, L. J.; JENKINS, A.; GRIZZETTI, B.; GALLOWAY, J. N.; VITOUSEK, P.; LEACH, A.; BOUWMAN, A. F.; BUTTERBACH-BAHL, K.; DENTENER, F.; STEVENSON, D.; AMANN, M.; VOSS, $\mathrm{M}$. The global nitrogen cycle in the twentyfirst century. Philosophical Transactions of the Royal Society B: Biological Sciences, v. 368, n. 1621, p. 20130164-20130164, 2013.

GALDINO, S.; GREGO, C. R. Distribuição espacial da erosividade da chuva na Bacia do Alto Paraguai, Brasil. In: $V$ SIMPÓSIO DE 
TÔSTO, K. L., PACHECO, F. S., GOMES, L., MIRANDA, M., OLIVEIRA, S. M. L., PESSI, D. D., COX, C., OMETTO, J. P. H. B.

\section{NITROGEN USE EFFICIENCY: A LOCAL AND REGIONAL APPROACH FOR BRAZILIAN AGRICULTURE}

GEOTECNOLOGIAS NO PANTANAL, 2014, Campo Grande, MS: Anais..., 2014, p.211-219.

GALLOWAY, J. N.; WINIWARTER, W.; LEIP, A.; LEACH, A. M.; BLEEKER, A.; ERISMAN, J. W. Nitrogen footprints: past, present and future. Environmental Research Letters, v. 9, n. 11, p. 115003, 2014.

GASQUES, J. G. .; BACCHI, M. P. R. .; RODRIGUES, L. .; BASTOS, E. T. .; VALDEZ, C. Produtividade da agricultura brasileira: a hipótese da deseceleração. In: VIEIRA FILHO, J. E. R. .; GASQUES, J. G. (Ed.). Agricultura, transformação produtiva e sustentabilidade. Brasília: Instituto de Pesquisa Econômica Aplicada (Ipea), 2016. p. 143-163.

GASQUES, J. G.; BACCHI, M. R. P.; BASTOS, E. T. Crescimento e produtividade da agricultura brasileira de 1975 a 2016. Carta de Conjuntura, n. 38, Instituto de Pesquisa Econômica Aplicada (Ipea), 2018. Disponível em: < http://www.ipea.gov.br/cartadeconjuntura/index .php/2018/03/02/crescimento-e-produtividadeda-agricultura-brasileira-de-1975-a-2016/>. Acesso em 20 junho 2018.

GOMES, L.; SIMÕES, S. J. C.; DALLA NORA, E. L.; SOUSA-NETO, E. R.; FORTI, M. C.; OMETTO, J. P. H. B.; DE SOUSA-NETO, E. R.; FORTI, M. C.; OMETTO, J. P. H. B. Agricultural Expansion in the Brazilian Cerrado: Increased Soil and Nutrient Losses and Decreased Agricultural Productivity. Land, v. 8, n. 1, p. 12, 2019.

HUBBARD, C.; ALVIM, A. M.; GARROD, G. Brazilian Agriculture as a Global Player. EuroChoices, v. 16, n. 1, p. 3-4, 2017.

HUNGRIA, M.; FRANCHINI, J. C.; CAMPO, R. J.; CRISPINO, C. C.; MORAES, J. Z.; SIBALDELLI, R. N. R.; MENDES, I. C.; ARIHARA, J. Nitrogen nutrition of soybean in Brazil: Contributions of biological $\mathrm{N} 2$ fixation and $\mathrm{N}$ fertilizer to grain yield. Canadian Journal of Plant Science, v. 86, n. 4, p. 927-939, 2006.

IBGE. Pesquisa Agrícola Municipal. Fundação Instituto Brasileiro de Geografia e Estatística, 2017.

Disponível em:<https://sidra.ibge.gov.br/pesquisa/pam/tab elas>. Acesso em 12 agosto 2018.

IBGE. Pesquisa Agrícola Municipal. Fundação Instituto Brasileiro de Geografia e Estatística, $2017 . \quad$ Disponível em:< https://sidra.ibge.gov.br/pesquisa/ids/tabelas>. Acesso em 20 julho 2018.

INSTITUTO SOS PANTANAL; WWF-BRASIL. Relatório Técnico Metodológico. Monitoramento das alterações da cobertura vegetal e uso do Solo na Bacia do Alto Paraguai - Porção Brasileira Período de Análise: 2012 a 2014. Brasília, 2015. $66 p$.

KANEKO, F. H.; LEAL, A. J. F.; ANSELMO, J. L.; BUZETTI, S.; TOSTA, F. da S. Fontes e manejos da adubação nitrogenada em algodoeiro. Pesquisa Agropecuária Tropical, v. 43, n. 1, p. 57-63, 2013.

KANTER, D. R.; SEARCHINGER, T. D. A technologyforcing approach to reduce nitrogen pollution. Nature Sustainability, v. 1, n. 10 , p. 544-552, 2018.

KANTER, D. R.; ZHANG, X.; HOWARD, C. M. Nitrogen and the Sustainable Development Goals. In: PROCEEDINGS OF THE 2016 INTERNATIONAL NITROGEN INITIATIVE CONFERENCE "SOLUTIONS TO IMPROVE NITROGEN USE EFFICIENCY FOR THE WORLD", 2016, Melbourne, Australia: Anais... 2016.

LAHSEN, M.; BUSTAMANTE, M. M. C.; DALLANORA, E. L. Undervaluing and Overexploiting the Brazilian Cerrado at Our Peril. Environment: Science and Policy for Sustainable Development, v. 58, n. 6, p. 4-15, 2016.

LAL, R. Soil conservation and ecosystem services. International Soil and Water Conservation Research, v. 2, n. 3, p. 36-47, 2014.

LAPOLA, D. M.; MARTINELLI, L. A.; PERES, C. A.; OMETTO, J. P. H. B.; FERREIRA, M. E.; NOBRE, C. A.; AGUIAR, A. P. D.; BUSTAMANTE, M. M. C.; CARDOSO, M. F.; COSTA, M. H.; JOLY, C. A.; LEITE, C. C.; MOUTINHO, P.; SAMPAIO, G.; STRASSBURG, B. B. N.; VIEIRA, I. C. G. Pervasive transition of the Brazilian land-use system. Nature Climate Change, v. 4, n. 1, p. 27-35, 2013. 
TÔSTO, K. L., PACHECO, F. S., GOMES, L., MIRANDA, M., OLIVEIRA, S. M. L., PESSI, D. D., COX, C., OMETTO, J. P. H. B.

\section{NITROGEN USE EFFICIENCY: A LOCAL AND REGIONAL APPROACH FOR BRAZILIAN AGRICULTURE}

LOVERDE-OLIVEIRA, S. M.; NASCIMENTO, F. A. Ecologia e História do Vale do São Lourenço. Rondonópolis. 2004, 57p.

MAPBIOMAS. Coleção 3 da Série Anual de Mapas de Cobertura e Uso de Solo do Brasil. Disponível em:

http://mapbiomas.org/pages/database/mapbiom as_collection_download>. Acesso em 20 junho 2018.

MARIN, F. R.; PILAU, G. P.; SPOLADOR, H. F. S.; OTTO, R. .; PEDREIRA, C. G. S. Intensificação sustentável da agricultura brasileira. Revista de Política Agrícola, v. 3, p. 108-124, 2016.

MATHUR, M.; GOEL, A. Quantitative atributes of nutrient uptake and use efficiency. In: NAEEM, M.; ANSARI, A. A.; GILL, S. S. (Ed.). Essential Plant Nutrients: Uptake, Use Efficiency, and Management. Switzerland: Springer International Publishing AG, 2017, c. 5, p. 81-117.

MORESCHI, I. C.; PAES, R. P. De; CALHEIROS, D. F. Poluição Difusa na Bacia Hidrográfica do Rio Miranda, Mato Grosso do Sul Diffuse Pollution in the Watershed of Miranda River, Mato Grosso Do Sul. Engineering and Science, v. 4, n. 2, p. 7286, 2015.

MOTOMIYA, W. R.; MOLIN, J. P.; MOTOMIYA, W. R.; VIEIRA, S. R. Spatial variability of soil properties and cotton yield in the Brazilian Cerrado and cotton yield in the Brazilian Cerrado 1 Variabilidade espacial de propriedades do solo e produtividade do algodoeiro no cerrado brasileiro. Revista Brasileira de Ciência do Solo, v. 15, n. 10, p. 996-1003, 2011.

NORTON, R.; DAVIDSON, E.; ROBERTS, T. Nitrogen use efficiency and nutrient performance Indicators. In: POSITION PAPER FROM GPNM'S TASK TEAM WORKSHOP, 2015, Washington, DC: Global Partnership on Nutrient Management. 2015, 1-14.

OENEMA O.; BRENTRUP F.; LAMMEL J.; BASCOU P.; BILLEN G.; DOBERMANN A.; ERISMAN J.W.; GARNETT T.; HAMMEL M.; HANIOTIS T.; HILLIER J.; HOXHA A.; JENSEN L.S.; OLESZEK W.; PALLIÈRE C.; POWLSON D.; QUEMADA M.; SCHULMAN M.;
SUTTON M.A.; Van GRINSVEN H.J.M.; WINIWARTER, W. Nitrogen use efficiency (NUE) an indicator for the utilization of nitrogen in food systems. EU Nitrogen Expert Panel, 2015: Wageningen, Netherlands. Disponível em: < http://www.eunep.com/reports/>. Acesso em 10 agosto 2018.

REAY, D. S.; HOWARD, C. M.; BLEEKER, A.; HIGINS, P.; SMITH, K.; ROOD, T.; THEOBALD, M. R.; COBEÑA, A. S.; REES, R. M.; MORAN, D.; REIS, S.; OTHERS. Societal choice and communicating the European nitrogen challenge. In: SUTTON, M. A.; HOWARD, C. M.; ERISMAN, J. W.; BILLEN, G.; BLEEKER, A.; GRENNFELT, P.; van GRINSVEN, H.; GRIZZETTI, B. The European Nitrogen Assessment. Cambridge: Cambridge University Press, 2011. cap. 11, p. 585-601.

BILLEN, G.; SILVESTRE, M.; GRIZZETTI, B.; LEIP, A.; GARNIER, J.; VOSS, M.; HOWARTH, R.; BOURAOUI, F.; LEPISTÖ, A.; KORTELAINEN, P.; JOHNES, P.; CURTIS, C.; HUMBORG, C.; SMEDBERG, E.; KASTE, Ø.; GANESHRAM, R.; BEUSEN, A.; LANCELOT, C. Nitrogen flows from European regional watersheds to coastal marine waters. In: SUTTON, M. A.; HOWARD, C. M.; ERISMAN, J. W.; BILLEN, G.; BLEEKER, A.; GRENNFELT, P.; van GRINSVEN, H.; GRIZZETTI, B. The European Nitrogen Assessment. Cambridge: Cambridge University Press, 2011. cap. 13, p. 271-297.

REIS, S.; BEKUNDA, M.; HOWARD, C. M.; KARANJA, N.; WINIWARTER, W.; YAN, X.; BLEEKER, A.; SUTTON, M. A. Synthesis and review: Tackling the nitrogen management challenge: From global to local scales. Environmental Research Letters, v. 11, n. 12, p. 120205, 2016.

SNYDER, C. S.; BRUULSEMA, T. W. Nutrient use efficiency and effectiveness in North America: indices of agronomic and environmental benefit. International Plant Nutrition Institute, 2007. Disponível em: <http://www.ipni.net/article/IPNI-3055>. Acesso em 20 agosto 2018. 
TÔSTO, K. L., PACHECO, F. S., GOMES, L., MIRANDA, M., OLIVEIRA, S. M. L., PESSI, D. D., COX, C., OMETTO, J. P. H. B.

\section{NITROGEN USE EFFICIENCY: A LOCAL AND REGIONAL APPROACH FOR BRAZILIAN AGRICULTURE}

SNYDER, C. S. Nitrogen Use Efficiency: global challenges, trends and the future. In: PROCEEDINGS OF THE SYMPOSIUM “NUTRIENT USE EFFICIENCY" - XVIII LATIN AMERICAN CONGRESS OF SOIL SCIENCE, 2009: International Plant Nutrition Institute, 2009, p. 10-17.

STEFFEN, W.; BROADGATE, W.; DEUTSCH, L.; GAFFNEY, O.; LUDWIG, C. The trajectory of the Anthropocene: The Great Acceleration. The Anthropocene Review, v. 2, n. 1, p. 81-98, 2015.

STEIN, L. Y.; KLOTZ, M. G. The Nitrogen Cycle. Current Biology, v. 26, n. 3, p. R94-R98, 2016.

STRASSBURG, B. B. N.; LATAWIEC, A. E.; BARIONI, L. G.; NOBRE, C. A.; DA SILVA, V. P.; VALENTIM, J. F.; VIANNA, M.; ASSAD, E. D. When enough should be enough: Improving the use of current agricultural lands could meet production demands and spare natural habitats in Brazil. Global Environmental Change, v. 28, p. 84-97, 2014.

STRASSBURG, B. B. N.; BROOKS, T.; FELTRANBARBIERI, R.; IRIBARREM, A.; CROUZEILLES, R.; LOYOLA, R.; LATAWIEC, A. E.; OLIVEIRA FILHO, F. J. B.; SCARAMUZZA, C. A. de M.; SCARANO, F. R.; SOARES-FILHO, B.; BALMFORD, A. Moment of truth for the Cerrado hotspot. Nature Ecology \& Evolution, v. 1, n. 4, p. 0099, 2017.
SUTTON, M.A.; BLEEKER, A.; HOWARD, C.M.; BEKUNDA, M.; GRIZZETTI, B.; DE VRIES, W.; VAN GRINSVEN, H.J.M.; ABROL, Y.P.; ADHYA, T.K.; BILLEN, G.; DAVIDSON, E.A.; DATTA, A.; DIAZ, R.; ERISMAN, J.W.; LIU, X.J.; OENEMA, O.; PALM, C.; RAGHURAM, N.; REIS, S.; SCHOLZ, R.W.; SIMS, T.; WESTHOEK, H.; ZHANG, F.S. Our Nutrient World: The challenge to produce more food and energy with less pollution. Edinburgh, NERC/Centre for Ecology \& Hydrology, 2013, 114pp.

UNITED NATIONS. The World Population Prospects: The 2017 Revision: World Population Prospects: The 2017 Revision, Key Findings and Advance Tables. Department of Economic and Social Affairs, Population Division: Working Paper No. ESA/P/WP/248, 2017.

VITOUSEK, P. M.; NAYLOR, R.; CREWS, T.; DAVID, M. B.; DRINKWATER, L. E.; HOLLAND, E.; JOHNES, P. J.; KATZENBERGER, J.; MARTINELLI, L. A.; MATSON, P. A.; NZIGUHEBA, G.; OJIMA, D.; PALM, C. A.; ROBERTSON, G. P.; SANCHEZ, P. A.; TOWNSEND, A. R.; ZHANG, F. S. Nutrient Imbalances in Agricultural Development. Science, v. 324, n. 5934, p. 1519-1520, 2009.

ZHANG, X.; DAVIDSON, E. A.; MAUZERALL, D. L.; SEARCHINGER, T. D.; DUMAS, P.; SHEN, Y. Managing nitrogen for sustainable development. Nature, v. 528, n. 7580, p. 1-9, 2015. 